\title{
Kinetics based reaction optimization of enzyme catalysed reduction of formaldehyde to methanol with synchronous cofactor regeneration
}

Marpani, Fauziah Binti; Sárossy, Zsuzsa ; Pinelo, Manuel; Meyer, Anne S.

\section{Published in:}

Biotechnology and Bioengineering

Link to article, DOI:

10.1002/bit.26405

Publication date:

2017

Document Version

Peer reviewed version

Link back to DTU Orbit

Citation (APA):

Marpani, F. B., Sárossy, Z., Pinelo, M., \& Meyer, A. S. (2017). Kinetics based reaction optimization of enzyme catalysed reduction of formaldehyde to methanol with synchronous cofactor regeneration. Biotechnology and Bioengineering, 114(12), 2762-2770. https://doi.org/10.1002/bit.26405

\section{General rights}

Copyright and moral rights for the publications made accessible in the public portal are retained by the authors and/or other copyright owners and it is a condition of accessing publications that users recognise and abide by the legal requirements associated with these rights.

- Users may download and print one copy of any publication from the public portal for the purpose of private study or research.

- You may not further distribute the material or use it for any profit-making activity or commercial gain

- You may freely distribute the URL identifying the publication in the public portal 


\section{Kinetics based reaction optimization of enzyme catalysed reduction of formaldehyde to methanol with synchronous cofactor regeneration ${ }^{\dagger}$}

Fauziah Marpani ${ }^{\mathrm{a}, \mathrm{b}}$, Zsuzsa Sárossy ${ }^{\mathrm{c}}$, Manuel Pinelo ${ }^{1}$, and Anne S. Meyer ${ }^{\mathrm{a}, *}$

Department of Chemical and Biochemical Engineering, Center for BioProcess Engineering, Building 229,

Technical University of Denmark, DK-2800 Kgs. Lyngby, Denmark

Faculty of Chemical Engineering, Universiti Teknologi MARA, 40450 Shah Alam, Selangor Darul Ehsan,

Malaysia

c Department of Chemical and Biochemical Engineering, Center for Combustion and Harmful Emission

Control, Building 229, Technical University of Denmark, DK-2800 Kgs. Lyngby, Denmark

* corresponding author: +45 45252800 (tel), +45 45882258 (fax), am@kt.dtu.dk]

tThis article has been accepted for publication and undergone full peer review but has not been through the copyediting, typesetting, pagination and proofreading process, which may lead to differences between this version and the Version of Record. Please cite this article as doi: [10.1002/bit.26405]

Additional Supporting Information may be found in the online version of this article.

This article is protected by copyright. All rights reserved

Received April 16, 2017; Revision Received July 9, 2017; Accepted August 14, 2017

This article is protected by copyright. All rights reserved 


\section{Abstract}

Enzymatic reduction of carbon dioxide $\left(\mathrm{CO}_{2}\right)$ to methanol $\left(\mathrm{CH}_{3} \mathrm{OH}\right)$ can be accomplished using a designed set-up of three oxidoreductases utilizing reduced pyridine nucleotide (NADH) as cofactor for the reducing equivalents electron supply. For this enzyme system to function efficiently a balanced regeneration of the reducing equivalents during reaction is required. Herein, we report the optimization of the enzymatic conversion of formaldehyde $(\mathrm{CHOH})$ to $\mathrm{CH}_{3} \mathrm{OH}$ by alcohol dehydrogenase, the final step of the enzymatic redox reaction of $\mathrm{CO}_{2}$ to $\mathrm{CH}_{3} \mathrm{OH}$, with kinetically synchronous enzymatic cofactor regeneration using either glucose dehydrogenase (System I) or xylose dehydrogenase (System II). A mathematical model of the enzyme kinetics was employed to identify the best reaction set-up for attaining optimal cofactor recycling rate and enzyme utilization efficiency. Targeted process optimization experiments were conducted to verify the kinetically modelled results. Repetitive reaction cycles were shown to enhance the yield of $\mathrm{CH}_{3} \mathrm{OH}$, increase the total turnover number (TTN) and the biocatalytic productivity rate (BPR) value for both system I and II whilst minimizing the exposure of the enzymes to high concentrations of $\mathrm{CHOH}$. System II was found to be superior to System I with a yield of $8 \mathrm{mM} \mathrm{CH}_{3} \mathrm{OH}$, a TTN of 160 and BPR of $24 \mu \mathrm{mol} \mathrm{CH}{ }_{3} \mathrm{OH} / \mathrm{U} \cdot \mathrm{h}$ during 6 hours of reaction. The study demonstrates that an optimal reaction set-up could be designed from rational kinetics modelling to maximize the yield of $\mathrm{CH}_{3} \mathrm{OH}$, whilst simultaneously optimizing cofactor recycling and enzyme utilization efficiency. This article is protected by copyright. All rights reserved

Keywords: Cofactors, Enzyme catalysis, Kinetics, Regeneration, xylose dehydrogenase, glucose dehydrogenase

This article is protected by copyright. All rights reserved 


\section{Introduction}

Carbon dioxide $\left(\mathrm{CO}_{2}\right)$ reduction to methanol $\left(\mathrm{CH}_{3} \mathrm{OH}\right)$ can be accomplished via an assembled multi-enzyme system comprised of three dehydrogenases: Formate dehydrogenase (EC 1.2.1.2), formaldehyde dehydrogenase (EC 1.2.1.46) and alcohol dehydrogenase (EC 1.1.1.1) (Obert and Dave, 1999). Each enzymatic step in this cascade system works in the reverse direction of the natural biological (reversible) enzyme catalysed reaction, but by careful attention to the reaction conditions the biological reaction equilibrium constants can be shifted by several orders of magnitude to favour $\mathrm{CH}_{3} \mathrm{OH}$ synthesis (Baskaya et al., 2010). Hence, in this designed set-up formate dehydrogenase catalyses conversion of gaseous $\mathrm{CO}_{2}$ into formate $\left(\mathrm{HCOOH}\right.$ or $\left.\mathrm{HCOO}^{-}\right)$, formaldehyde dehydrogenase catalyses reduction of the $\mathrm{HCOO}^{-}$to formaldehyde $(\mathrm{CHOH})$, and finally alcohol dehydrogenase (ADH) catalyses the conversion of formaldehyde into $\mathrm{CH}_{3} \mathrm{OH}$ (Obert and Dave, 1999). In this system all three enzymes employ the same cofactor, the reduced form of nicotinamide adenine dinucleotide (NADH), to supply the reducing equivalents required for reaction. Such biocatalytic reduction of $\mathrm{CO}_{2}$ is an attractive option for reducing $\mathrm{CO}_{2}$ emissions because of the option for simultaneously providing for a new supply route of current fossil-oil-derived chemicals such as $\mathrm{CHOH}$ and $\mathrm{CH}_{3} \mathrm{OH}$. In addition, the reaction can be accomplished at mild reaction conditions, notably at low temperature. However, since each reaction step in the enzymatic cascade system consumes one $\mathrm{NADH}$ cofactor equivalent, three moles of reduced $\mathrm{NADH}$ are required to convert one mole of $\mathrm{CO}_{2}$ to $\mathrm{CH}_{3} \mathrm{OH}$. This requirement makes effective recycling of reducing equivalents, i.e. cofactor regeneration, essential in practice. Various technologies, including coupling of the enzyme system to chemical and photochemical (Dibenedetto et al., 2012), electrochemical (Alissandratos and Easton, 2015) or bioelectrochemical systems (Srikanth et al., 2014; Srikanth et al., 2017) or combinations hereof (Zhang et al., 2017) have been suggested, but the most common method for accomplishing NADH regeneration for dehydrogenase catalysed reactions is by converting the oxidized form of the cofactor ( $\left.N A D^{+}\right)$directly to its reduced form (NADH) in situ by addition of a second enzyme and a second substrate (Hummel and Gröger, 2014; Luo et al., 2015). In addition to cost-efficiency, cofactor recycling may also prevent enzyme inhibition by the cofactor (van der Donk and Zhao, 2013). A feasible approach to accomplish the enzyme catalysed This article is protected by copyright. All rights reserved 
cofactor regeneration is by coupling of the regeneration to other value-added reactions, e.g. as reported for other reactions such as reduction of xylose to xylitol (consumes NADH) coupled with oxidation of glycerol to dihydroxy-acetone (consumes $\mathrm{NAD}^{+}$) as the cofactor regenerative reaction (Zhang et al., 2011).

Process optimization of coupled reactions commonly requires laborious experimentation. Considering the underlying mechanism of kinetics of each reaction, kinetic models may however be developed to simulate the biocatalytic process and predict a defined optimal performance (Braun et al., 2011).

In this study, the final step of the multi-enzymatic reaction for $\mathrm{CO}_{2}$ conversion to $\mathrm{CH}_{3} \mathrm{OH}$, catalysed by ADH, was selected as the productive reaction to be coupled with enzymatic in situ NADH cofactor regeneration. Two coupling reaction systems were evaluated. System I included ADH and glucose dehydrogenase (GDH) and System II included ADH and xylose dehydrogenase (XDH) (Scheme 1). Each system was carefully selected to form a profitable setup. The products from each recycling reaction (gluconic acid and xylonic acid, respectively) have thus been categorized by the US Department of Energy to be among the top 30 potential basic precursors relevant for synthesis of high value chemicals and fuels (Werpy and Petersen, 2004). To the best of our knowledge, the use of XDH is new in this application.

For the system to work optimally, the reaction design requires a balancing of the forward reaction rate and the cofactor regeneration reaction rate. The hypothesis behind the work undertaken was that an optimal compromise of reaction variables, i.e. ratio of enzymes, substrates, and initial NADH concentration could be identified to maximize the yield of $\mathrm{CH}_{3} \mathrm{OH}$, total turnover number (TTN) and biocatalytic productivity rate $(B P R)$ in the enzymatic reaction with NADH regeneration.

Hence, the overall objective of the study was to identify the optimal reaction conditions for ADH catalysis to favour and maximize enzyme catalysed conversion of $\mathrm{CHOH}$ to $\mathrm{CH}_{3} \mathrm{OH}$ with efficient in situ cofactor regeneration and simultaneously optimize the utilization of the enzymes to achieve high yield of $\mathrm{CH}_{3} \mathrm{OH}$. The approach was to apply mathematical models derived from the ordered bi-bi mechanism of ADH (Findrik et al., 2005) to describe the forward and reverse kinetics of the productive and regenerative enzyme reactions in a batch reactor, and on this basis conduct rationally designed repetitive batch experiments to verify the optimal reaction conditions.

This article is protected by copyright. All rights reserved 


\section{Materials and Methods}

\section{Materials}

Alcohol dehydrogenase (ADH, EC 1.1.1.1) from Saccharomyces cerevisae, glucose dehydrogenase (GDH, EC 1.1.1.118) from Pseudomonas sp. (1 Unit of GDH converts $1 \mu$ mole $\beta$-D-glucose per minute in the presence of $\mathrm{NAD}^{+}$), nicotineamide adenine dinucleotide $\left(\mathrm{NAD}^{+}, \mathrm{NADH}\right)$, pure $\mathrm{CHOH}$ (analytical standard), D-glucose, D-xylose, D-gluconic acid, D-xylonic acid, Trizma base and hydrochloric acid (37\%) were purchased from Sigma-Aldrich (Saint Louis, MO, USA). Xylose dehydrogenase (XDH, EC 1.1.1.175) was obtained from Megazyme (Co. Wicklow, Ireland) (1 Unit of XDH converts $1 \mu$ mole of NADH to NAD per minute in the presence of $\beta$-D-xylose). All enzyme and substrate solutions were prepared using $0.1 \mathrm{M}$ Tris- $\mathrm{HCl}$ buffer (pH $=7.0)$ unless otherwise stated.

\section{Determination of kinetics parameters}

Determination of kinetic parameters was based on the forward and reverse reactions of the enzymes. NADH/NAD ${ }^{+}$, D-Glucose, D-xylose, $\mathrm{CHOH}$ and $\mathrm{CH}_{3} \mathrm{OH}$, and enzyme stock solutions (ADH, GDH, XDH) were prepared in $100 \mathrm{mM}$ Tris- $\mathrm{HCl}$ buffer (pH 7). Each reaction was performed in a cuvette with a total volume of $2 \mathrm{ml}$. The initial reaction velocities were calculated from rates of NADH consumption or formation by monitoring the absorbance at $340 \mathrm{~nm}$ using a UV-VIS spectrophotometer, Ultrospec 2100 pro (GE Healthcare, Little Chalfont, UK). The range of concentrations applied in the experiments is summarized in Table S1 (supplementary). The kinetic parameters were obtained from Hanes-Woolf plots.

\section{Stability of enzymes}

Enzymes (ADH, GDH and XDH) were incubated separately in $100 \mathrm{mM}$ Tris- $\mathrm{HCl}$ buffer (pH 7) with different concentrations of $\mathrm{CHOH}(10,20$ and $40 \mathrm{mM}$ ) using a thermomixer (Eppendorf, Hamburg, Germany) at room temperature $\left(23^{\circ} \mathrm{C}\right)$ and shaken at $300 \mathrm{rpm}$. At set time intervals, an amount of incubated enzyme was sampled for its respective assay (Table S2) containing NADH for activity determination. The conversion to the reduced or oxidized form of NADH was recorded by monitoring the absorbance at $340 \mathrm{~nm}$ in a UV-VIS spectrophotometer, Ultrospec 2100 pro (GE healthcare, Little Chalfont, UK). For each enzyme the denaturation constant, $\mathrm{k}_{\mathrm{D}}$ was determined assuming first order exponential decay (Leuchs et al., 2013).

This article is protected by copyright. All rights reserved 


\section{Batch reactor experiment}

Coupled reactions of System I or System II were conducted in $1.5 \mathrm{ml}$ Eppendorf tubes using a thermomixer (Eppendorf, Hamburg, Germany) set at room temperature $\left(23{ }^{\circ} \mathrm{C}\right)$ and shaken at $300 \mathrm{rpm}$. The concentration of substrate and enzyme were prepared in $100 \mathrm{mM}$ tris- $\mathrm{HCl}$ buffer $(\mathrm{pH} \mathrm{7.0)}$ according to the optimum parameters combination from the simulation. The reaction was started by adding initial concentration of $50 \mu \mathrm{M}$ of NADH. At timed intervals, $200 \mu \mathrm{l}$ of the solution was sampled. Each reaction was heat deactivated for sugar analysis. For measuring methanol, samples were analyzed directly at the timed interval without deactivation. It is worth noting that all the Eppendorf tubes placed on the sample holder were covered with aluminium foil to prevent UV light penetration.

\section{Repetitive batch experiment}

Repetitive batch experiments were performed in $25 \mathrm{ml}$ flasks, covered with aluminium foil, at room temperature $\left(23^{\circ} \mathrm{C}\right)$. At time intervals, $100-200 \mu \mathrm{l}$ samples were withdrawn from the reactor. A new amount of substrates were added in the reactor after the initial levels were converted. Substrates added were dissolved in a small amount of buffer to compensate the volume loss in the previous cycle.

\section{Mathematical model for the coupled reaction}

The kinetic modelling of acetophenone reduction with NADH regeneration in the batch reactor was based on models of Findrik et al. (2005). Three kinetic equations were considered (Table S3): $r_{1}$ model the conversion of $\mathrm{CHOH}$ to $\mathrm{CH}_{3} \mathrm{OH}$ (forward), $r_{2}$ model the conversion of $\mathrm{CH}_{3} \mathrm{OH}$ to $\mathrm{CHOH}$ (reverse) and $r_{3}$ model the conversion of D-glucose to D-gluconic acid or D-xylose to D-xylonic acid (forward). Commerciallyavailable software, MATLAB with the ODE45 function was used for solving the kinetic model together with mass balance equations and using the parameters determined for individual reactions.

\section{Performance index}

Besides TTN, the performance index for the regenerative reaction was used to observe the biocatalytic productivity rate. The definitions are:

TTN $=($ Product formed $(\mathrm{mol})) /($ Total cofactor added in the reaction $(\mathrm{mol}))$

BPR $\left(\mu \mathrm{mol} \mathrm{CH}{ }_{3} \mathrm{OH} / \mathrm{U} \cdot \mathrm{h}\right)=\left(\right.$ Yield of $\left.\mathrm{CH}_{3} \mathrm{OH}(\mu \mathrm{M})\right) /(($ Total concentration of enzymes $(\mathrm{U} / \mathrm{ml}) \cdot$ Reaction time $(\mathrm{h}))$

This article is protected by copyright. All rights reserved 


\section{Analytical methods}

The methanol concentration of the samples was analyzed by gas chromatography - mass spectrometry (GC-MS) using a Hewlett Packard HP 6890 gas chromatograph interfaced to a HP5973 Mass Selective Detector (Agilent, Denmark). Samples $(1 \mu \mathrm{l})$ were injected in split mode (1:20) using an HP 7683 autosampler (Agilent, Denmark). The source and rod temperatures were $230^{\circ} \mathrm{C}$ and $150{ }^{\circ} \mathrm{C}$, respectively. The products were separated using a $0.32 \mathrm{~mm}$ i.d. x $25 \mathrm{~m}$ PLOT fused silica column coated with PORAPLOT

$U$ at a thickness of $0.10 \mu \mathrm{m}$ (Analytical, Denmark). The carrier gas was He at a flow rate of $1.2 \mathrm{ml} / \mathrm{min}$. Separation of products was achieved using a temperature program from $70{ }^{\circ} \mathrm{C}$ to $200{ }^{\circ} \mathrm{C}$ at $10{ }^{\circ} \mathrm{C} / \mathrm{min}$. The applied ionization energy was $70 \mathrm{eV}$. Full mass spectra were recorded every $0.3 \mathrm{~s}$ (mass range $\mathrm{m} / \mathrm{z} 40-\mathrm{m} / \mathrm{z}$ 450). Products were identified using NIST search engine version $2.0 \mathrm{f}$. (Agilent, Denmark).

In order to differentiate between the stable isotope methanol content and the natural methanol content extracted ion chromatograms (EIC) were collected. A selected ion pair was used for quantification and here $\mathrm{m} / \mathrm{z}$ 31/33 was chosen for EIC analysis.

Glucose, xylose, gluconic acid and xylonic acid were quantified by high performance anion exchange chromatography with pulsed amperometric detection (HPAED-PAD) using a Dionex ICS-5000 system (Dionex Corp., Sunnyvale, CA) equipped with a CarboPac PA1 guard column (4 x $50 \mathrm{~mm}$ ) and a CarboPac PA1 analytical column $(4 \times 250 \mathrm{~mm})$ with a flow rate of $1 \mathrm{~mL} / \mathrm{min}$.

Isocratic elution took place at $0.5 \mathrm{mM} \mathrm{NaOH}$ for $40 \mathrm{~min}$. Afterwards, the column was washed for $10 \mathrm{~min}$ with $500 \mathrm{mM} \mathrm{NaOH}$ and re-equilibrated with $0.5 \mathrm{mM} \mathrm{NaOH}$ for 10 min. with a post column addition of 500 $\mathrm{mM} \mathrm{NaOH}$ at a flow rate of $0.2 \mathrm{~mL} / \mathrm{min}$. External standards of D-glucose, D-xylose, D-gluconic acid and Dxylonic acid were used for quantification.

\section{Results and Discussion}

Kinetics assessment

The kinetics parameters were determined individually for each enzyme reaction from classic, systematic enzyme kinetics experiments, including the $\mathrm{ADH}$ catalysed reactions $\left(\mathrm{CHOH} \rightarrow \mathrm{CH}_{3} \mathrm{OH}\right.$ and $\mathrm{CH}_{3} \mathrm{OH} \rightarrow \mathrm{CHOH}$ )

This article is protected by copyright. All rights reserved 
and both of the NADH regenerative reactions, the data obtained are summarized Table 1 . For ADH the higher $\mathrm{K}_{\mathrm{m}}$ for $\mathrm{CH}_{3} \mathrm{OH}$ than for $\mathrm{CHOH}$ indicates that $\mathrm{CH}_{3} \mathrm{OH}$ may indeed accumulate in the reaction. From the data in Table 1 it is also evident that the $K_{m}$ for both NAD and the co-substrate is much higher for GDH than for XDH hinting that XDH may be kinetically more suitable for NADH regeneration than GDH. The kinetic parameters were employed in a mathematical enzyme kinetics model for kinetic rate determination of both the forward NADH consuming reaction and the NADH co-factor regenerating reactions in System I and

II (Table S1).

Stability of enzymes and cofactors

Information on the enzyme stability at the required reaction conditions is a crucial prerequisite for determining the robustness of the enzymes during reaction and to design the experimental setup for an optimum process operation. The first step was therefore to investigate the stability of enzymes in $\mathrm{CHOH}$. It is the simplest aldehyde, known as a toxic metabolite which may cause irreversible inhibition of enzyme proteins by reacting with amino acid side chains forming covalent adducts. NADH is stable in base but labile in acid, whereas NAD is labile in base (Chenault and Whitesides, 1987). UV light has been demonstrated to increase the rate of decay of NADH (Wykes et al., 1975), hence, the experiment set up was designed to prevent direct UV exposure, and with reaction at $\mathrm{pH} 7 . \mathrm{ADH}$ is stable at 10 and $20 \mathrm{mM} \mathrm{CHOH}$ for at least 13 hours before it loses half of the activity. Increasing $\mathrm{CHOH}$ to $40 \mathrm{mM}$ requires only 13 minutes for the activity to drop by 50\% (Figure SI). Both GDH and XDH are more stable in $\mathrm{CHOH}$ (higher t/1/2) than ADH (Table

2). Considering the multi-enzymatic reaction of $\mathrm{CO}_{2}$ to methanol and the low solubility of $\mathrm{CO}_{2}$ in water $(<1.4$ $\left.\mathrm{g} \mathrm{CO}_{2} / \mathrm{L}\right), \mathrm{CHOH}$ produced from the two consecutive steps $\left(\mathrm{CO}_{2}\right.$ to $\mathrm{CHOOH}$ to $\left.\mathrm{CHOH}\right)$ will not be particularly high at ambient temperature; the $\mathrm{CHOH}$ concentration was therefore set at $10 \mathrm{mM}$ in the model.

Biocatalytic process modelling

The reaction trajectory of nicotinamide adenine nucleotide-dependent dehydrogenases generally follows an ordered bi-bi reaction mechanism (Leskovac, 2004; Rudolph and Fromm, 1970). The mechanistic model for $\mathrm{ADH}$ in redox biocatalysis of $\mathrm{CHOH}$ to $\mathrm{CH}_{3} \mathrm{OH}$ can therefore be illustrated by the nucleotide being the first substrate to bind to the enzyme followed by $\mathrm{CHOH}$ to form a ternary complex. The main product,

This article is protected by copyright. All rights reserved 
$\mathrm{CH}_{3} \mathrm{OH}$, then leaves the enzyme after the conversion, followed by the nucleotide, being the last product to dissociate. In the case of two substrates, a simplified two-substrate Michaelis-Menten equation combined with one product and/or substrate inhibition is usually used (Vasic-Racki et al., 2003). A comprehensive model, taking into account both the forward and reverse reactions was therefore developed in MATLAB and applied to describe overall reaction rate models in order to relate the kinetics and the substrate and product concentrations by the differential system including non-linear functions (Vasic-Racki et al., 2003).

\section{Selection of regenerative enzymes}

Although the direct reduction of $\mathrm{CHOH}$ to $\mathrm{CH}_{3} \mathrm{OH}$ is non-thermodynamically favoured, it was discovered that the $\mathrm{ADH}$ catalysed reaction is almost irreversible due to low affinity of $\mathrm{CH}_{3} \mathrm{OH}$ as substrate (high $\mathrm{K}_{\mathrm{m}}$ value) (Table 1). In the reaction, the regenerative substrate (glucose/xylose) is transformed into its respective ketone (glucono-lactone/xylono-lactone) which spontaneously converts to a sugar acid (gluconic/xylonic acid). The sugar acid cannot retransform into glucose/xylose at this point and the reaction can thus be treated as irreversible, driving the conversion of $\mathrm{CHOH}$ to $\mathrm{CH}_{3} \mathrm{OH}$.

Both GDH and XDH had low $K_{m}$ values (Table 1), hence low substrate concentrations are needed and there is only low risk of inhibition.

\section{Simulation approach towards process optimization}

The amounts of enzyme and cofactor have significant influence on the operation cost, thus, the process optimization objective is to identify a compromise between efficiency and maximum yield. Besides the objective of generating a high yield of $\mathrm{CH}_{3} \mathrm{OH}$, the key performance for cofactor recycling was to attain a high TTN and high enzyme utilization efficiency by achieving a high BPR. A high $\mathrm{CH}_{3} \mathrm{OH}$ yield will not guarantee a good BPR. There are several variables in the coupled reactions; i.e amount of each type of enzyme, substrate concentrations, initial amount of cofactor.

A reaction time of 6 hours was preset based on the $t \frac{1}{2}$ information of each enzyme (Table 2 ). An initial NADH concentration of $0.05 \mathrm{mM}$ was selected; two times the $K_{m}$ value for ADH (Table 2) to ensure complete saturation and to ascertain that the enzyme was working at its maximum velocity. $V_{\max }$ values 
were simulated as a function of different combinations of substrate concentrations. TTN and BPR were calculated according to the yield of $\mathrm{CH}_{3} \mathrm{OH}$.

Initial selection of substrate concentrations for optimization

The ratios of enzymes to substrates are important to ensure that the reaction reaches equilibrium at a designated time. $\mathrm{K}_{m}$ of $\mathrm{CHOH}$ is higher than the $\mathrm{K}_{\mathrm{m}}$ for the regenerating substrates (Table 1 ).

Basically, a higher $\mathrm{K}_{\mathrm{m}}$ shows low affinity of the enzyme towards the substrate and hence, requires a high substrate concentration for the enzyme to be saturated. On the other hand, a low concentration of regenerating substrates is sufficient for the reaction to proceed (lower $K_{m}$ ). As mentioned, the concentration of $\mathrm{CHOH}$ was fixed at $10 \mathrm{mM}$ for both systems I and II. Based on the $\mathrm{K}_{\mathrm{m}}$, regenerating substrates could be set lower. From the model, increasing glucose and xylose to more than $4 \mathrm{mM}$ did not increase methanol yield in 6 hours batch reaction, most likely as a result of the putative substrate inhibition effects (substrate inhibition was considered in the model (Table S3)), and accordingly the BPR generally decreased with higher regenerating substrate concentration (Figure 1).

As a direct consequence of the better kinetic parameters of the XDH than the GDH, including notably the lower $\mathrm{K}_{\mathrm{m}}$ values for the monosaccharide oxidation reaction and the $\mathrm{NAD}^{+} \rightarrow \mathrm{NADH}$ reaction (Table 1 ), the BPR levels were consistently better for XDH than for $\mathrm{GDH}$ within the similar ranges of $\mathrm{CH}_{3} \mathrm{OH}$ yields attained within the 6 hours reaction on $10 \mathrm{mM} \mathrm{CHOH}$ (Figure 1).

Visualization of system efficiency on an XY plane

The effect of enzymes activity concentration on TTN and BPR resulting from hundreds of simulations can be visualized by projecting the data on XY planes (Figure 2). Considering $2 \mathrm{mM}$ of regenerating substrates to be equilibrated with $10 \mathrm{mM} \mathrm{CHOH}$, TTN had an upper limit of 40 while BPR showed an upper limit of 50 $\mu \mathrm{mol} / \mathrm{U} \cdot \mathrm{h}$ with System I. For System II, TTN and BPR achieved upper limits of 40 and $63 \mu \mathrm{mol} / \mathrm{U} \cdot \mathrm{h}$, respectively. A trade-off between $T T N$ and BPR was evident. Combination of higher productive and regenerative enzymes concentrations tended to increase TTN (Figure 2a and e), whereas a high BPR region was achieved by combination of lower enzyme concentrations (Figure $2 b$ and f). From intersecting the maximum region of TTN and BPR the best compromise of ADH concentration and regenerative enzymes

This article is protected by copyright. All rights reserved 
concentrations could be identified; the simulated optimum data point regions are indicated by a cross symbol (Figure 2) and summarized in Table 3. A lower concentration of XDH was ideal in System II (Figure $2 \mathrm{~g}$ and $\mathrm{h}$ ). Combining at least $55 \mathrm{Uml}^{-1} \mathrm{ADH}$ with $0.5 \mathrm{Uml}^{-1} \mathrm{XDH}$ attained the upper limit of TTN. In contrast, GDH concentration had to be set at least at $4 \mathrm{Uml}^{-1}$ to achieve an optimum compromise of TTN and BPR in System I (Table 3).

Model validation in batch reaction

To evaluate the model, 6 hour time course experiments were conducted by applying the optimum combinations of process variables calculated from the model (Table 3). In System I, the model predicted the $\mathrm{CH}_{3} \mathrm{OH}$ concentration well when coupling with 1 and $2 \mathrm{mM}$ of glucose in 6 hours reaction. The conversion of glucose reached $100 \%$ in 6 hours at the glucose concentrations assessed (Figure 3). Coupling with $3 \mathrm{mM}$ glucose produced only $85 \%$ conversion. In System II, 100\% conversion of the xylose was achieved with 1, 2 and $3 \mathrm{mM}$ of xylose within 6 hours (Figure 3).

\section{Model validation in repetitive batch}

Repetitive batch experiments were designed for both systems in order to increase the yield of $\mathrm{CH}_{3} \mathrm{OH}$ as well as to minimize the detrimental effect of $\mathrm{CHOH}$ towards the enzymes. The substrates were added at specified time intervals to keep the ceiling concentration of $\mathrm{CHOH}$ at $10 \mathrm{mM}$. In System I, initially $2 \mathrm{mM}$ glucose and $10 \mathrm{mM}$ of $\mathrm{CHOH}$ were added to a $25 \mathrm{ml}$ volume reactor. After 2 hours of reaction (based on the reaction completion time, Figure 3), $2 \mathrm{mM}$ glucose and $\mathrm{CHOH}$ mixed in a small volume of buffer were added, and 3 cycles of reaction were accomplished in 6 hours (Figure 4). In System II, 2 mM of xylose and $\mathrm{CHOH}$ were added after 1.5 hours, and this resulted in 4 cycles reaction in 6 hours (Figure 5). Comparison of the system efficiencies, summarized in Table 4, clearly shows that the approach could enhance the yield of $\mathrm{CH}_{3} \mathrm{OH}$ by at least 2 fold for both systems. System II produced the highest yield with $8 \mathrm{mM} \mathrm{CH} \mathrm{CH}_{3} \mathrm{OH}$. This $\mathrm{CH}_{3} \mathrm{OH}$ yield and the doubling of $\mathrm{CH}_{3} \mathrm{OH}$ formation per se with the co-factor recycling represent a profound improvement compared to previous work (e.g. Liu et al. 2015). It is possible that the reusability of the enzymes (BPR) may be enhanced by enzyme immobilization as enzyme immobilization may increase yields as originally shown by Obert and Dave (Obert and Dave, 1999) and later by others using various enzyme

This article is protected by copyright. All rights reserved 
immobilization systems (e.g. Jiang et al., 2003; Xu et al., 2006; Sun et al., 2009; Shi et al., 2012; Cazelles et al., 2013; Wang et al., 2014; Ji et al., 2015). The kinetic modeling approach employed in the present work may be extrapolated to optimizing such systems as well.

\section{Conclusion}

A kinetic model derived from an ordered bi-bi reaction mechanism for ADH was applied to identify the optimum process variables for enzymatic conversion of $\mathrm{CHOH}$ to $\mathrm{CH}_{3} \mathrm{OH}$ by $\mathrm{ADH}$ coupled with in situ enzymatic NADH cofactor regeneration. Based on well-characterized reaction kinetics the model successfully predicted the optimum working concentrations of both productive and regenerative enzymes and co-substrates that could equilibrate the maximum concentration of substrates within 6 hours of reaction. Good performance of cofactor recycling was indicated with a high TTN whereas high BPR portrayed efficient enzyme utilization. A trade-off between TTN and BPR was evident.

The experimental and simulated data were in excellent agreement indicating that the model could describe the behaviour of the bi-enzymatic system. In order to avoid a detrimental effect of $\mathrm{CHOH}$ to enzymes as well as to increase the yield of $\mathrm{CH}_{3} \mathrm{OH}$, repetitive batch setups were designed for both system I and II. The setup was demonstrated to increase $\mathrm{CH}_{3} \mathrm{OH}$ yield by at least 2 fold in comparison with a batch reaction. System II employing XDH for NADH regeneration was found to be more efficient than system I producing at least $8 \mathrm{mM} \mathrm{CH} \mathrm{H}_{3} \mathrm{OH}$ yield, TTN of 160 and $\mathrm{BPR}$ of $24 \mu \mathrm{mol} \mathrm{CH}_{3} \mathrm{OH} / \mathrm{U} \cdot \mathrm{h}$ in 6 hours reaction. The findings enhance our understanding of how a balanced regeneration of NADH reducing equivalents can be accomplished during enzymatic reaction and have implications for development of enzymatic $\mathrm{CO}_{2}$ conversion to $\mathrm{CH}_{3} \mathrm{OH}$. The enzymes used were purchased for biochemical research and had not been selected or engineered for optimizing robustness nor had their production been cost-minimized. Hence, it is too early to include cost analyses. The results nevertheless provide a foundation on which continued technological advancements can be made to promote further explorations of enzymatic $\mathrm{CO}_{2}$ conversion.

This article is protected by copyright. All rights reserved 


\section{Acknowledgements}

FM thanks Ministry of Higher Education Malaysia and Universiti Teknologi MARA for the scholarship award.

\section{Statement}

All authors declare no conflicts of interest.

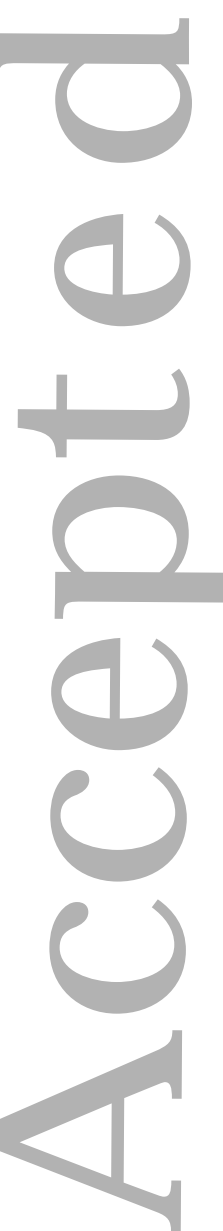

This article is protected by copyright. All rights reserved 


\section{References}

Alissandratos A, Easton CJ. 2015. Biocatalysis for the applicatioin of $\mathrm{CO}_{2}$ as a chemical feedstock. Beilstein J Org Chem 11: 2370-2387.

Baskaya FS, Zhao X, Flickinger MC, Wang P. 2010. Thermodynamic feasibility of enzymatic reduction of carbon dioxide to methanol. Appl Biochem Biotechnol 162: 391-398.

Braun M, Link H, Liu L, Schmid RD, Weuster-Botz D. 2011. Biocatalytic process optimization based on mechanistic modeling of cholic acid oxidatoni with cofactor regeneration. Biotechnol Bioeng 108: $1307-1317$.

Cazelles R, Drone J, Fajula F, Ersen O, Moldovan S, Galarneau A. 2013. Reduction of $\mathrm{CO}_{2}$ to methanol by a polyenzymatic system encapsulated in phospholipids-silica nanocapsules. New J Chem 37:37213730.

Chenault HK, Whitesides GM. 1987. Regeneration of nicotinamide cofactors for use in organis synthesis. Appl Biochem Biotechnol 14: 147-197.

Dibenedetto A, Stufano P, Macyk W, Brana T, Fragale C, Costa M, Aresta M. 2012. Hybrid technologies for an enhanced carbon recycling based on the enzyamtic reduction of $\mathrm{CO}_{2}$ to methanol in water: Chemical and photochemical regeneration. ChemSusChem 5: 373-378.

Findrik Z, Vasic-Racki D, Lütz S, Daussmann T, Wandrey C. 2005. Kinetic modeling of acetophenone reduction catalyzed by alcohol dehydrogenase from Thermoanaerobacter sp. Biotechnol Lett 27:1087-1095.

Hummel W, Gröger H. 2014. Strategies for regeneration of nicotinamide coenzymes emphasizing selfsufficient closed-loop recycling systems. J Biotechnol 191: 22-31.

Ji X, Su Z, Wang P, Ma G, Zhang S. 2015. Tethering of nicotinamide adenine dinucleotide inside hollow nanofibers for high-yield synthesis of methanol from carbon dioxide catalyzed by coencapsulated multienzymes. ACS Nano 9: 4600-4610.

Jiang Z, Wu H, Xu S, Huang S. 2003. Enzyamtic conversion of carbon dioxide to methanol by dehydrogenases encapsulated in sol-gel matrix. ACS Symp Ser. 852: 212-218.

This article is protected by copyright. All rights reserved 
Leskovac V. 2004. Comprehensive Enzyme Kinetics, Kluwer Academic Publishers, New York, USA.

Leuchs S, Nonnen T, Dechambre D, Na'amnieh S, Greiner L. 2013. Continuous biphasic enzymatic reduction of aliphatic ketones. J Mol Catal B Enzym 88: 52-59.

Luo J, Meyer AS, Mateiu R, Pinelo M. 2015. Cascade catalysis in membranes with enzyme immobilizatioin for multi-enzymatic conversion of $\mathrm{CO}_{2}$ to methanol. New Biotechnol 32:319-327.

Obert R, Dave BC. 1999. Enzymatic conversion of carbon dioxide to methanol: Enhanced methanol production in silica sol-gel matrices. J Am Chem Soc 121: 12192-12193.

Rudolph FB, Fromm HJ. 1970. Use of isotope competition and alternative substrates for studying kinetic mechanism of enzyme action. 1. Experiments with hexokinase and alcohol dehydrogenase. Biochemistry 9: 4660-4665.

Shi J, Wang X, Jiang Z, Liang Y, Zhu Y, Zhang C. 2012. Constructing spatially separated multienzyme system through bioadhesion-assisted bio-inspired mineralization for efficient carbon dioxide conversion. Bioresour Technol 118: 359-366.

Srikanth S, Alvarez-Gallego Y, Vanbroekhoven K, Pant D. 2017. Enzymatic electrosynthesis of formic acid through carbon dioxide reduction in a bioelectrochemical system: Effect of immobilization and carbonic anhydrase addition. ChemPhysChem, record on-line DOI: 10.1002/cphc.201700017

Srikanth S, Maesen M, Dominguez-Benetton X, Vanbroekhoven K, Pant D. 2014. Enzymatic electrosynthesis of formate through $\mathrm{CO}_{2}$ sequestration/reduction in a bioelectrochemical system (BES). Bioresour Technol 165: 350-354.

Sun $Q$, Jiang $Y$, Jiang Z, Zhang L, Sun X, Li J. 2009. Green and efficient conversion of $\mathrm{CO}_{2}$ to methanol by biomimetic coimmobilization of three dehydrogenases in protamine-templated titania. Ind Eng Chem Res 48: 4210-4215.

van der Donk WA, Zhao HM. 2003. Recent developments in pyridine nucleotide regeneration. Curr Opin Biotechnol 14:421-426.

Vasic-Racki D, Kragl U, Liese A. 2003. Benefits of enzyme kinetics modelling. Chem Biochem Eng Q 17: 7-18. Wang X, Li Z, Shi J, Wu H, Jiang Z, Zhang W. 2014. Bioinspired appraoch to multienzyme cascade system

This article is protected by copyright. All rights reserved 
construction for efficient carbon dioxide reduction. ACS Catal 4: 962-972.

Werpy T, Petersen G. 2004. Top Value Added Chemicals from Biomass Volume I - Results of Screening for Potential Candidates from Sugars and Synthesis Gas, U.S. Department of Energy, National Renewable Energy Laboratory. http://www.nrel.gov/docs/fy04osti/35523.pdf; accessed April 10. 2017.

Wykes JR, Dunnill P, Lilly MD. 1975. Cofactor recycling in an enzyme reactor - Comparison using free and immobilized dehydrogenases with free and immobilized NAD. Biotechnol Bioeng 17: 51-68.

Xu S, Lu Y, Li J, Jiang Z, Wu H. 2006. Efficient conversion of $\mathrm{CO}_{2}$ to methanol catalyzed by three dehydrogenases co-encapsulated in an alginate-silica $\left(\mathrm{ALG}-\mathrm{SiO}_{2}\right)$ hybrid gel. Ind Eng Chem Res 45: 4567-4573.

Zhang Y, Gao F, Zhang SP, Su ZG, Ma GH, Wang P. 2011. Simultaneous production of 1,3-dihydroxyacetone and xylitol from glycerol and xylose using a nanoparticle-supported multi-enzyme system with in situ cofactor regeneration. Bioresour Technol 102:1837-1843.

Zhang L, Ong J, Liu J, Li SFY. 2017. Enzymatic electrosynthesis of formate from $\mathrm{CO}_{2}$ reduction in a hybrid biofuel cell system. Renew Energy 108:581-588.

This article is protected by copyright. All rights reserved 


\section{Legend to Scheme 1}

Scheme 1. Conversion of $\mathrm{CHOH}$ to $\mathrm{CH}_{3} \mathrm{OH}$ coupled with in situ NADH cofactor regeneration featuring System I with glucose dehydrogenase (GDH) and System II with xylose dehydrogenase (XDH).

This article is protected by copyright. All rights reserved 


\section{Figure legends}

Figure 1. $\mathrm{CH}_{3} \mathrm{OH}$ yields (columns) and $\mathrm{BPR}$ (black dots) responses to different regenerative substrate concentrations that could be equilibrated with $10 \mathrm{mM} \mathrm{CHOH}$ in 6 hours reaction; (a) System I (b) System II.

Figure 2. Projection of TTN and BPR against enzyme concentration for System I $\left(\gamma_{\mathrm{CHOH}}=10 \mathrm{mM}, \gamma_{\text {glucose }}=2\right.$

$\mathrm{mM})$ and System II ( $\left.\gamma_{\mathrm{CHOH}}=10 \mathrm{mM}, \gamma_{\mathrm{xyllose}}=2 \mathrm{mM}\right)$.

Figure 3. $\mathrm{CH}_{3} \mathrm{OH}$ formation in a batch reactor within 6 hours with $10 \mathrm{mM}$ initial $\mathrm{CHOH}$ and different concentrations of regenerating substrates; (System I) $\gamma_{\mathrm{ADH}}=55 \mathrm{Uml}^{-1}, \gamma_{\mathrm{GDH}}=4 \mathrm{Uml}^{-1}$, blue circle $\gamma_{\mathrm{Glucose}}=1$ $\mathrm{mM}$, red circle $\gamma_{\text {Glucose }}=2 \mathrm{mM}$, green circle $=3 \mathrm{mM}$, grey line model; (System II) $\gamma_{\mathrm{ADH}}=55 \mathrm{Uml}^{-1}, \gamma_{\mathrm{XDH}}=0.5$ $\mathrm{Uml}^{-1}$, purple circle $\gamma_{x y l o s e}=1 \mathrm{mM}$, black circle $\gamma_{x y l o s e}=2 \mathrm{mM}$, orange circle $\gamma_{x y l o s e}=3 \mathrm{mM}$, grey line model.

Figure 4. $\mathrm{CH}_{3} \mathrm{OH}$ formation in the repetitive batch reactor of System I $\left(\gamma_{\mathrm{ADH}}=55 \mathrm{Uml}^{-1}, \gamma_{\mathrm{GDH}}=4 \mathrm{Uml}^{-1}, \gamma_{\mathrm{NADH}}=\right.$ $0.05 \mathrm{mM}, \gamma_{\mathrm{CHOH}, 1}=10 \mathrm{mM}, \gamma_{\mathrm{CHOH}, 2}=9.7 \mathrm{mM}, \gamma_{\mathrm{CHOH}, 3}=9.7 \mathrm{mM}, \gamma_{\text {Glucose }, 1}=2 \mathrm{mM}, \gamma_{\text {Glucose }, 2}=2.3 \mathrm{mM}, \gamma_{\text {Glucose }, 3}=$ $2.3 \mathrm{mM}$; grey line model, blue circle cycle 1, red circle cycle 2, green circle cycle 3).

Figure 5. Methanol formation in the repetitive batch reactor of System II $\left(\gamma_{A D H}=55 \mathrm{Uml}^{-1}, \gamma_{\mathrm{XDH}}=0.5 \mathrm{Uml}^{-1}\right.$, $\gamma_{\mathrm{NADH}}=0.05 \mathrm{mM}, \gamma_{\mathrm{CHOH}, 1}=10 \mathrm{mM}, \gamma_{\mathrm{CHOH}, 2}=9.7 \mathrm{mM}, \gamma_{\mathrm{CHOH}, 3}=9.7 \mathrm{mM}, \gamma_{\text {xylose }, 1}=2 \mathrm{mM}, \gamma_{\text {xylose }, 2}=2.3 \mathrm{mM}$, Yxylose,3 $=2.3 \mathrm{mM}$; grey line model, blue circle cycle 1, red circle cycle 2, green circle cycle 3, purple circle cycle 4).

This article is protected by copyright. All rights reserved 
Table 1. Kinetic parameters for $A D H, G D H$, and XDH.

\begin{tabular}{llll}
\hline Enzyme & Reaction & $\begin{array}{l}\mathrm{K}_{\mathbf{m}} \\
(\mathbf{m M})\end{array}$ & $\begin{array}{l}\mathbf{V}_{\max } \\
(\boldsymbol{\mu m o l} / \mathbf{m g} \cdot \mathbf{m i n})\end{array}$ \\
\hline $\mathrm{ADH}$ & $\mathrm{CHOH} \rightarrow \mathrm{CH}_{3} \mathrm{OH}$ & 6 & 6 \\
& $\mathrm{NADH} \rightarrow \mathrm{NAD}^{+}$ & 0.025 & 4.7 \\
& $\mathrm{CH}_{3} \mathrm{OH} \rightarrow \mathrm{CHOH}$ & 100 & 0.019 \\
& $\mathrm{NAD}^{+} \rightarrow \mathrm{NADH}$ & 0.36 & 0.015 \\
\hline $\mathrm{GDH}$ & $\mathrm{Glucose} \rightarrow \mathrm{Gluconic}$ acid & 2.2 & 8.8 \\
& $\mathrm{NAD} \rightarrow \mathrm{NADH}$ & 30 & 6.3 \\
\hline $\mathrm{XDH}$ & $\mathrm{Xylose} \rightarrow$ Xylonic acid $^{+}$ & $9.8 \times 10^{-4}$ & $0.62^{\mathrm{a})}$ \\
& $\mathrm{NAD}^{+} \rightarrow \mathrm{NADH}$ & 0.04 & $0.56^{\text {a) }}$ \\
\hline
\end{tabular}

Unit in $\mu \mathrm{mol} / \mathrm{U} \cdot \mathrm{min}$ 
Table 2. Deactivation constant, $k_{D}$ and half-life, $t_{1 / 2}$ of enzymes in $10 \mathrm{mM} \mathrm{CHOH}$.

\begin{tabular}{lll}
\hline Enzyme & $\mathrm{k}_{\mathrm{D}}^{\mathrm{a})}$ & $\mathrm{t}_{\frac{1}{2}(\mathrm{~h})}$ \\
\hline $\mathrm{ADH}$ & $0.0553 \pm 0.4042$ & 12.5 \\
$\mathrm{GDH}$ & $0.0284 \pm 0.0788$ & 24.4 \\
$\mathrm{XDH}$ & $0.0079 \pm 0.1451$ & 87.7 \\
\hline
\end{tabular}

a) Deactivation constant

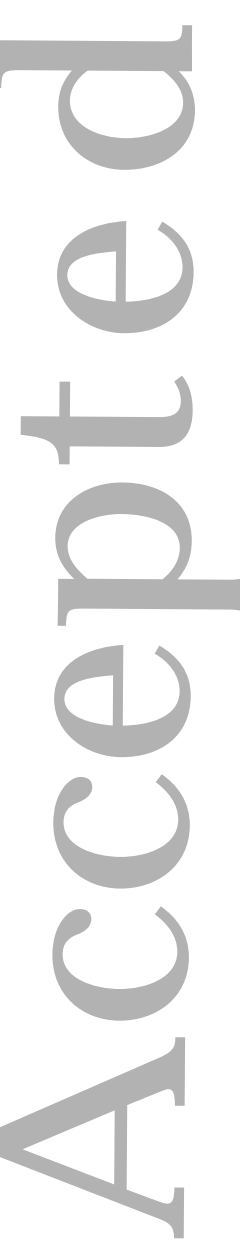

This article is protected by copyright. All rights reserved 
Table 3. Optimum range of enzyme and substrate concentrations simulated from the kinetic model

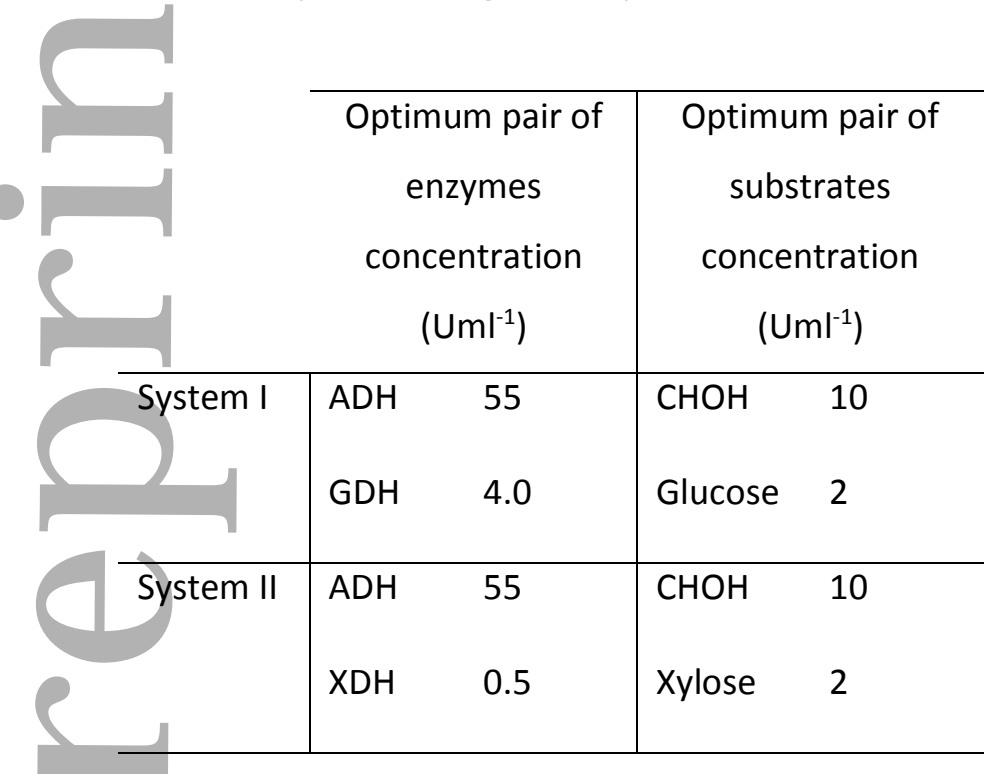

This article is protected by copyright. All rights reserved 
Table 4. Comparison of system efficiencies in different reactor set up in 6 hours reaction, RepBatch is Repetitive Batches as shown in Figures 4 and 5.

\begin{tabular}{|lcc|cc}
\hline System & \multicolumn{2}{c|}{ System I } & \multicolumn{2}{c}{ System II } \\
\cline { 2 - 5 } efficiency & Batch & RepBatch & Batch & RepBatch \\
\hline $\begin{array}{l}\mathrm{CH}_{3} \mathrm{OH} \text { yield } \\
(\mathrm{mM})\end{array}$ & 2.6 & 5.6 & 3.0 & 8.0 \\
\hline $\begin{array}{l}\mathrm{BPR}(\mu \mathrm{mol} \\
\left.\mathrm{CH} \mathrm{H}_{3} \mathrm{OH} / \mathrm{U} \cdot \mathrm{h}\right)\end{array}$ & 7.3 & 15.8 & 9.0 & 24.0 \\
\hline $\begin{array}{l}\text { Total turnover } \\
\text { number (TTN) }\end{array}$ & 52.0 & 112.0 & 60.0 & 160.0 \\
\hline
\end{tabular}

This article is protected by copyright. All rights reserved 


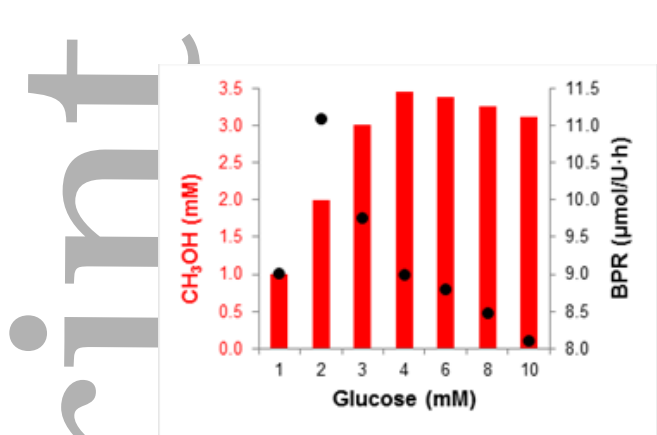

Figure 1(a)
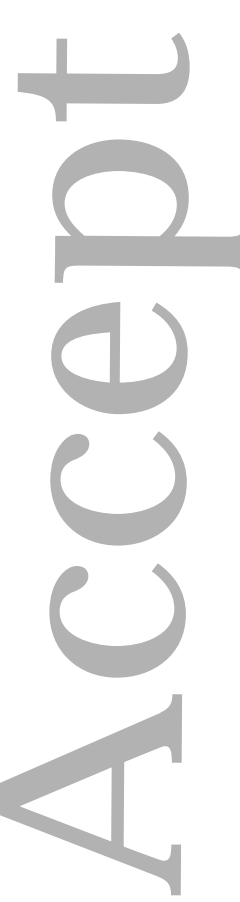

This article is protected by copyright. All rights reserved 

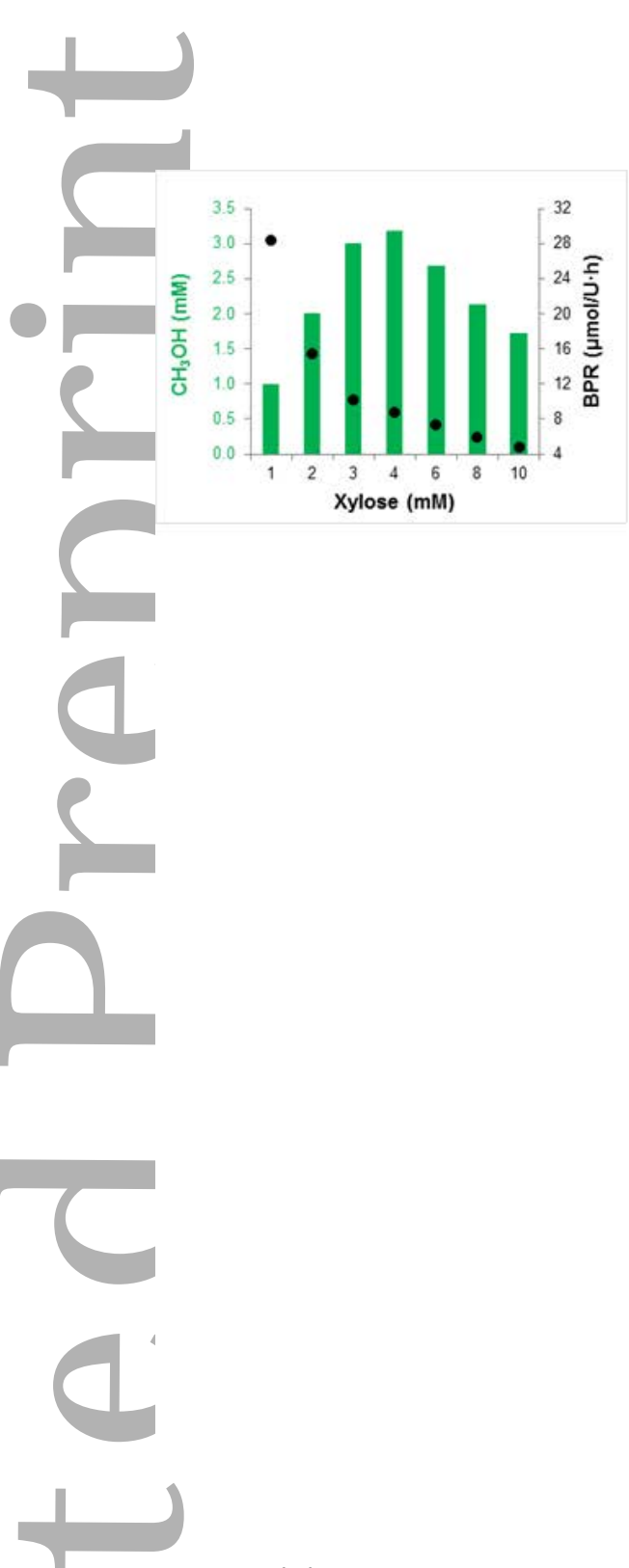

Figure 1(b)

This article is protected by copyright. All rights reserved 
System I (ADH - GDH)

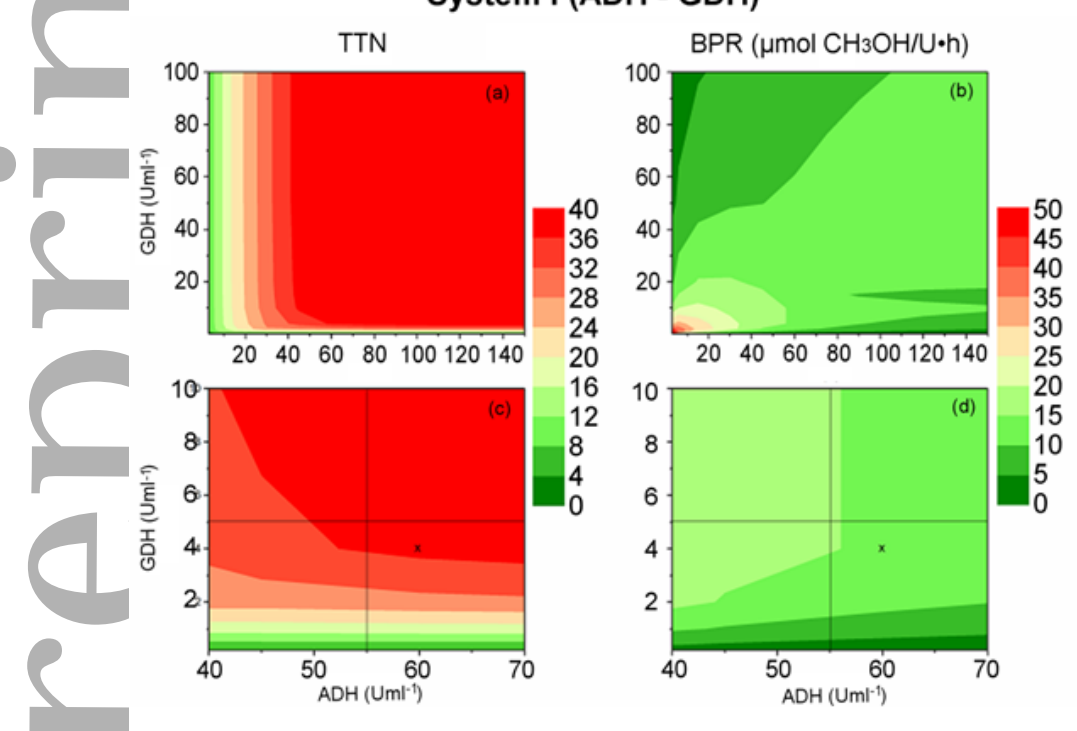

Figure 2

This article is protected by copyright. All rights reserved 
System II (ADH - XDH)

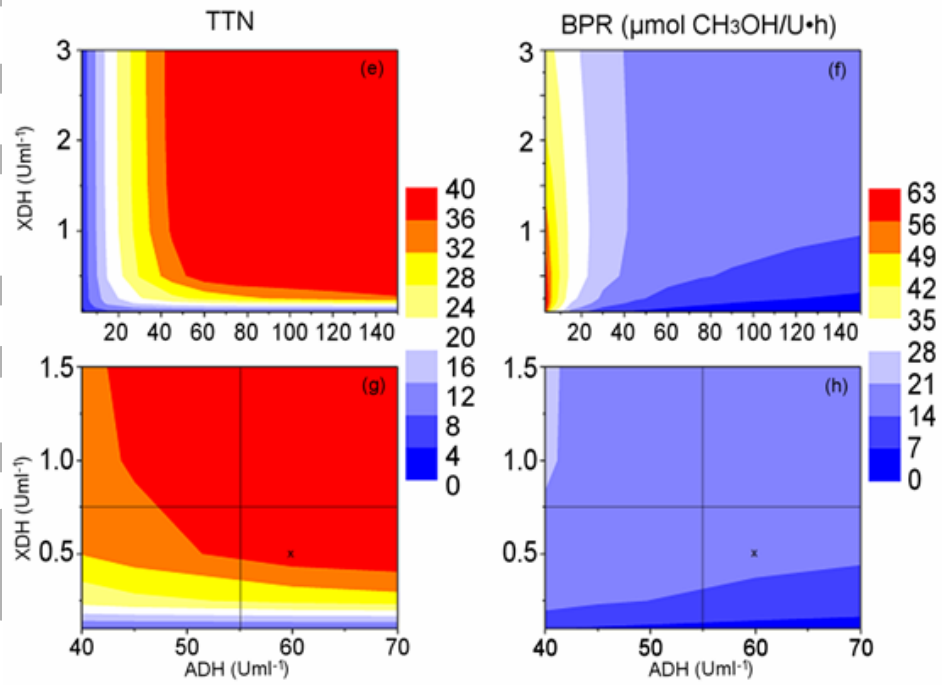

Figure 2

This article is protected by copyright. All rights reserved 


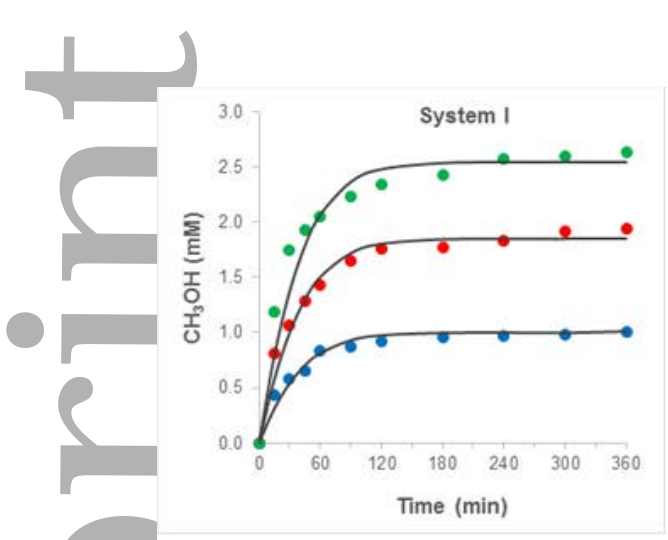

Figure 3

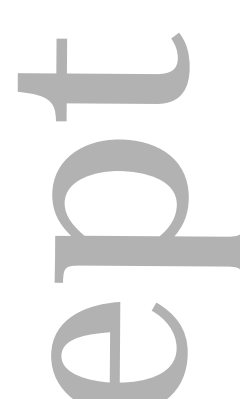

This article is protected by copyright. All rights reserved 


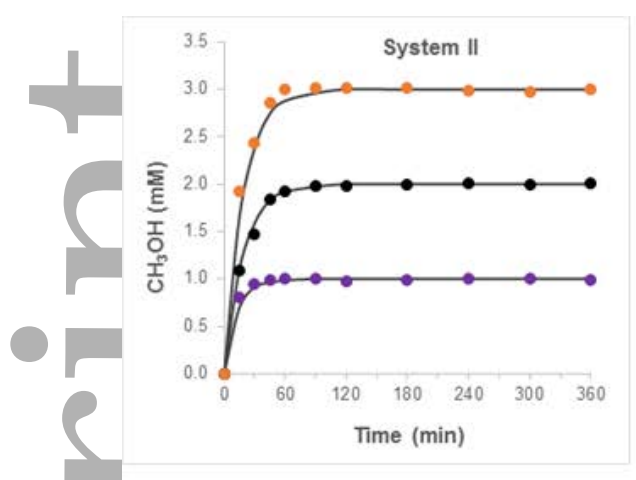

Figure 3

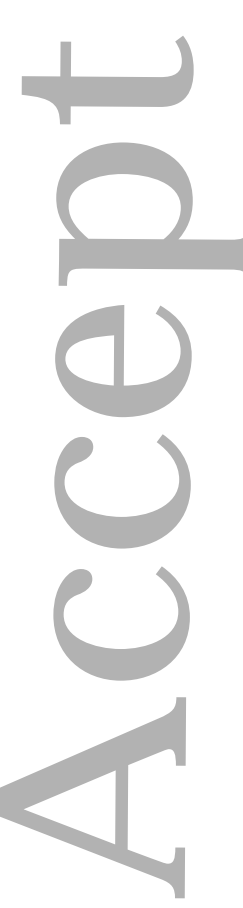

This article is protected by copyright. All rights reserved 


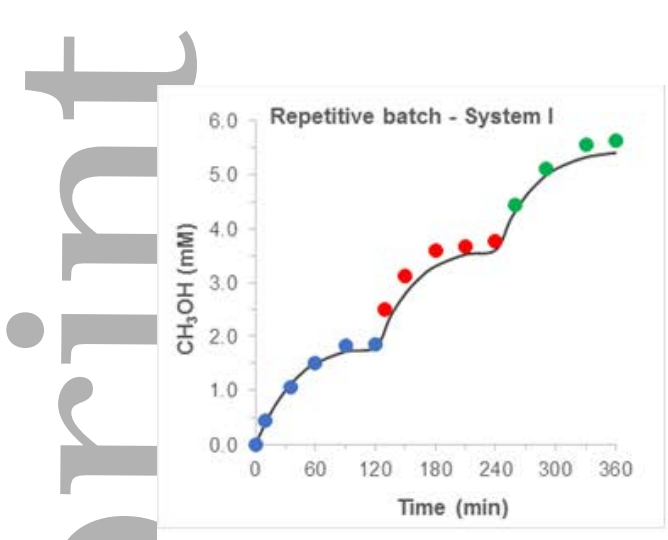

Figure 4

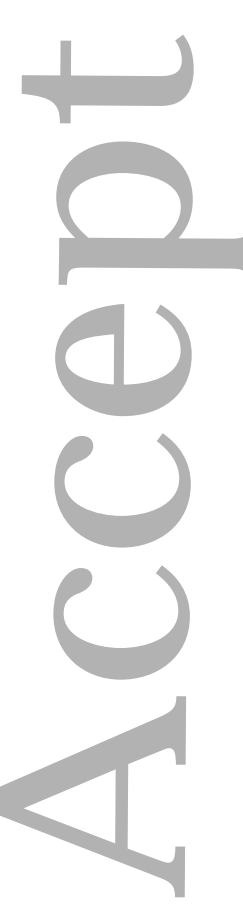

This article is protected by copyright. All rights reserved 


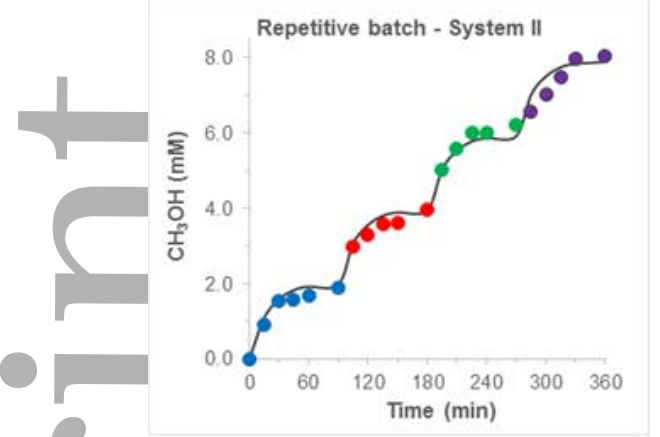

Figure 5
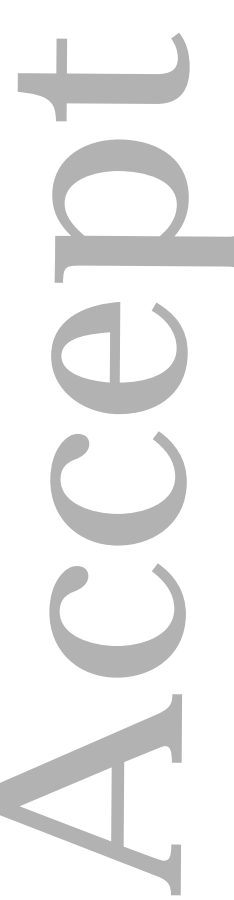

This article is protected by copyright. All rights reserved 

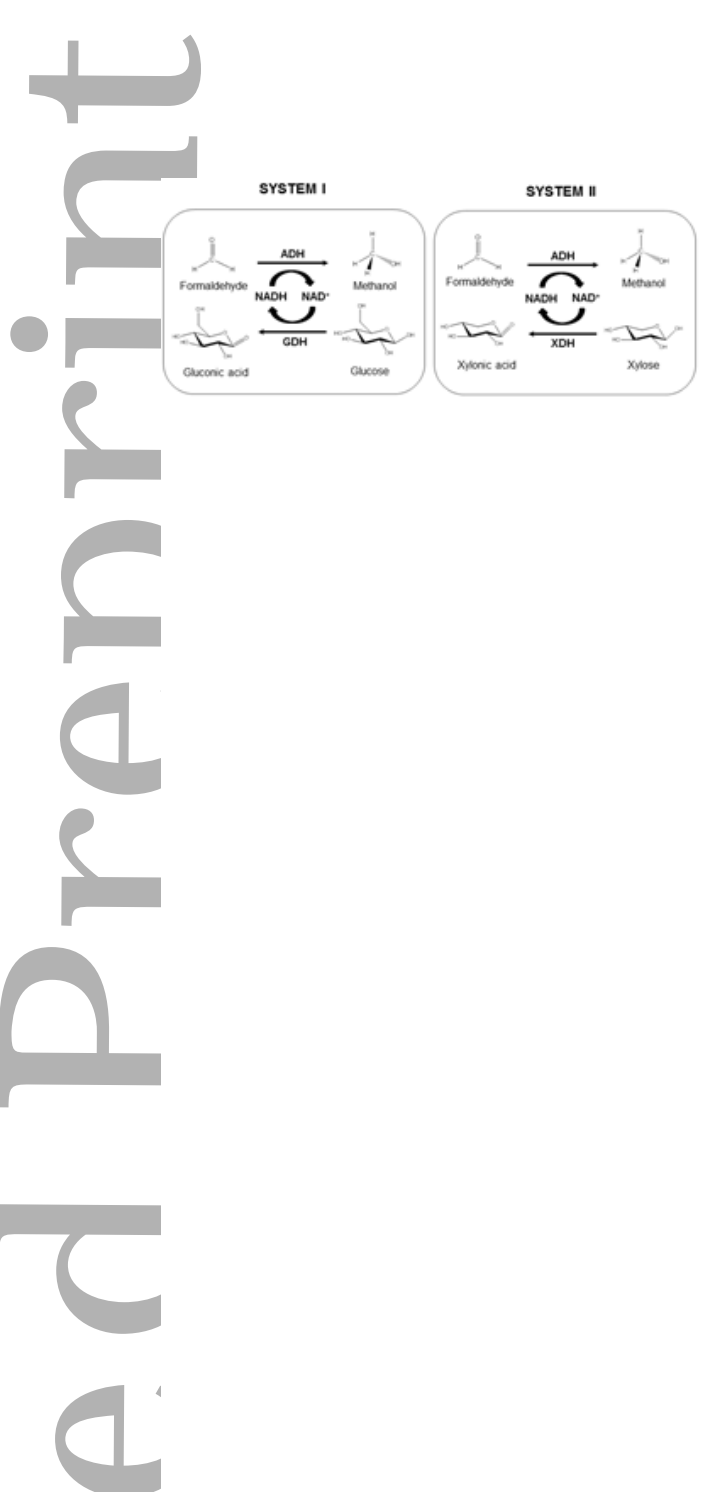

Scheme 1

This article is protected by copyright. All rights reserved 